Supporting Information for

\title{
Global and national environmental impacts of the US- China trade war
}

Jianhong Lu ${ }^{1,2}$, Xianqiang Mao ${ }^{*}, 1,2$, Mudan Wang ${ }^{1,2}$, Zhengyan Liu²,3, Peng Song ${ }^{4}$

${ }^{1}$ School of Environment, Beijing Normal University, No. 19 Xinjiekouwai Street, Beijing 100875, P. R. China

${ }^{2}$ Center for Global Environmental Policy, Beijing Normal University, No. 19 Xinjiekouwai Street, Beijing 100875, P. R. China

${ }^{3}$ Institute of Spatial Planning and Regional Economy, China Academy of Macroeconomic Research, Beijing 100038, P. R. China

${ }^{4}$ School of Public Affairs, Center for Public Economy \& Public Policy Research, Chongqing University, No. 174 Shazheng street, Chongqing 400044, P. R. China

* Corresponding author. Tel.: +86 10 58807812; fax: +86 1058807812.

E-mail address: maoxq@,bnu.edu.cn (X. Q. Mao). 


\section{Contents}

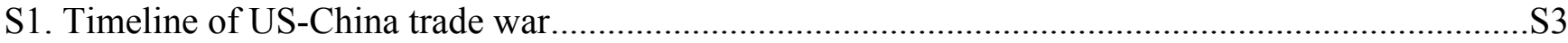

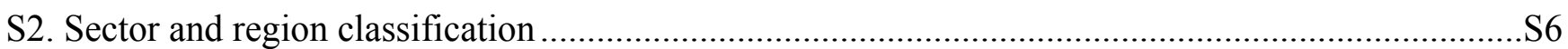

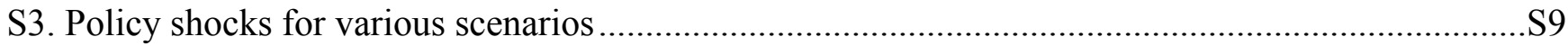

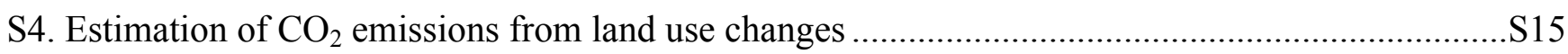

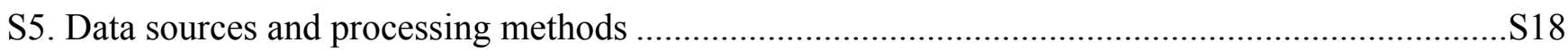

S6. Predicted country/economy-wide and sectoral $\mathrm{CO}_{2}$ emission changes ...........................................

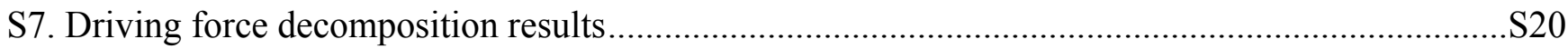

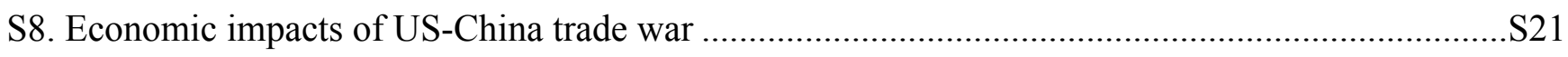

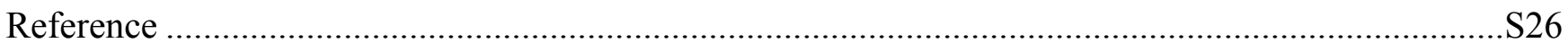

Pages: 28

Figures: 5

Tables: 6 


\section{S1. Timeline of US-China trade war}

The US and China are the world's two largest economies, and the trade volume between the two countries accounts for $23 \%$ of world trade. Especially after China's accession to the WTO in 2001, bilateral trade between China and the US has developed more rapidly. According to the UN Comtrade database ${ }^{1}$, the value of their bilateral trade in goods rose from $\$ 80.6$ billion in 2001 to $\$ 584.8$ billion in 2017 , accounting for $14.2 \%$ and $16.6 \%$ of the total values of trade in goods of China and the US in 2017 , respectively.

The rapid and stable growth of US-China trade is related to the considerable differences in the production factors of the two countries and the strong complementarity in their industrial competitiveness. China's exports to the US are mainly mechanical and electrical products, accounting for $50.8 \%$ of China's total exports to the US, followed by furniture, toys, textiles, raw materials and base metals and products. Of the total US exports to China, soybeans, cotton, cars, integrated circuits, and Boeing aircraft are the main goods. ${ }^{2}$

Although the economic and trade exchanges between the two countries are mutually complementary, trade friction has always existed. The trade friction between the two countries escalated into a "trade war". On July 6,2018 , the US officially imposed an extra 25\% tariff on imports from China, which was valued at $\$ 34$ billion. Since then, the US has launched a number of waves of taxation "sanctions" against China, and China reacted with countermeasures of retaliatory tariffs. The battlefield of the trade war has continued to expand. Mexico and the European Union have also become involved. The US threatened Mexico by increasing the tariffs on its exports to the US to rein in illegal migration. In addition, tariffs have been levied on $\$ 7.5$ billion in EU exports to the US, including Airbus aircrafts, cheese, wine and olives. (see Figure $\mathbf{S 1}$ for the timeline) 


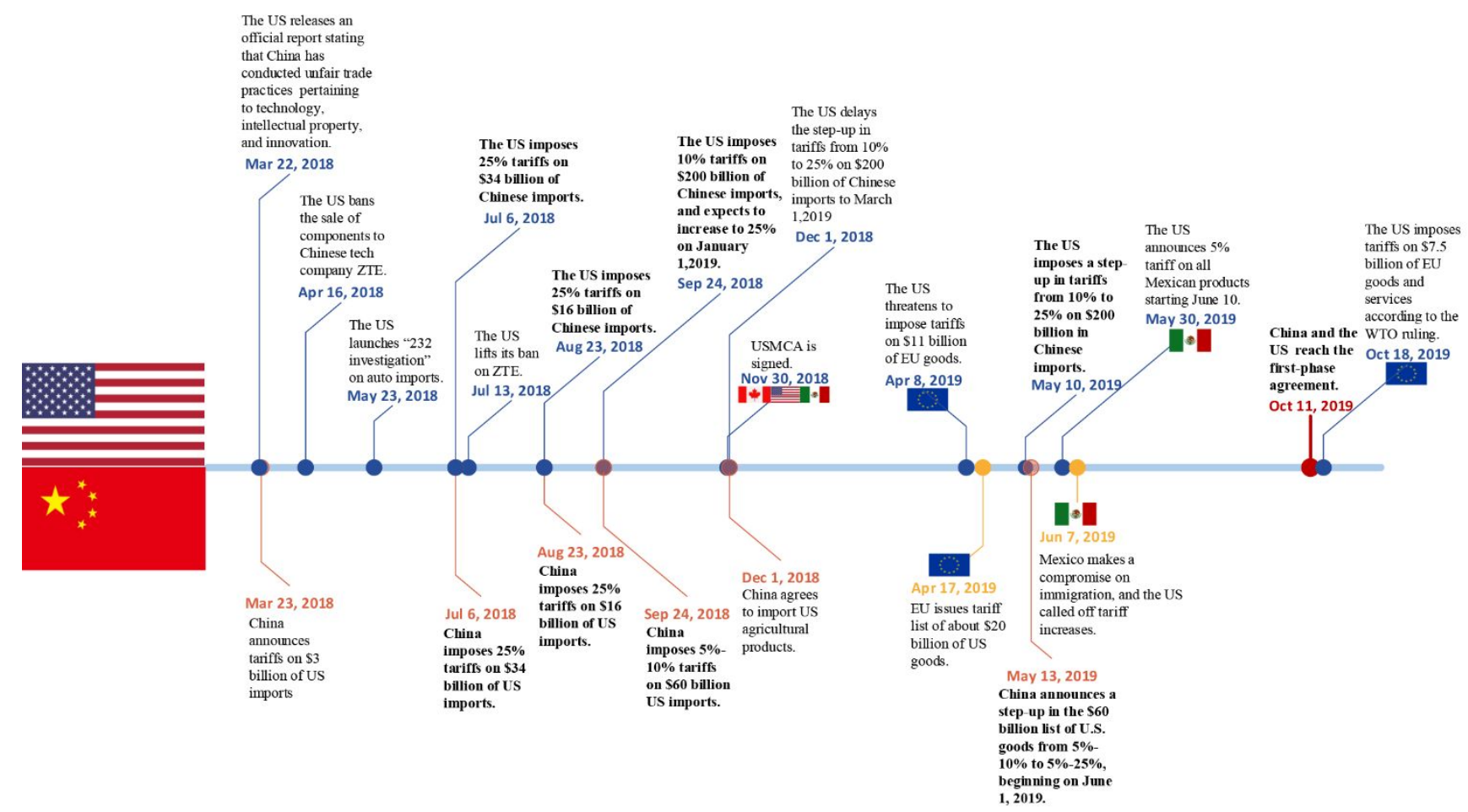

Figure S1. Timeline of US-China trade war measures taken by both countries (Drawn by the authors)

On October 11, 2019, China and the US reached the first-phase agreement, which eased the trade war. However, the trade war shocked the trade and economic paradigm of the two countries and even the world and increased the uncertainty of global economic development. Possible impacts of the trade war have drawn research attentions from investors and academics.

Goldman Sachs ${ }^{3}$ and Nicita ${ }^{4}$ assessed the impacts of trade wars and concluded that although it has narrowed the trade deficit of the US with China, its negative impacts on the economy of China and the US cannot be ignored. Goldman Sachs ${ }^{3}$ lowered its forecast for growth in the GDP of the US by $0.5 \%$ to $2.0 \%$ and asserted that tariffs inflated the US prices and affected the revenue of Chinese exporters. Amiti, et al. ${ }^{5}$ argued that the impact of tariff changes was almost entirely passed on to US importers and consumers. However, Zoller-Rydzek and Felbermayr ${ }^{6}$ thought that Chinese companies would bear approximately $75 \%$ of the tariffs, and Chinese companies' producer prices would fall more than the average consumer prices in 
the US. Although there is still controversy at this point, most studies agree that the trade war has a negative impact on the GDP and welfare of China and the US 5, 7-10.

In addition, the impacts of the trade war have spilled over to other countries and economies, such as Brazil. China, as the world's largest soybean importer, relies heavily on imported soybean for the production of animal feed and cooking oil in China ${ }^{11}$. As trade retaliatory measures, China reduced its soybean purchases from the US and turned to Brazil to make up for the supply gap ${ }^{12,13}$. Fuchs, et al. ${ }^{14}$ expected that China's demand would lead Brazil to increase soybean production by 22.6-37.6 million tons, requiring an increase of 12.9 million hectares of farmland. The trade diversion effect brought by the trade war seems to have benefited non-Chinese mainland producers in Mexico and Canada in and East and Southeast Asian economies to varying degrees $^{3,15,16}$. There were reports that manufacturers were leaving mainland China and moving to neighboring Vietnam, Korea and Taiwan Province of China, among others ${ }^{4}$. 


\section{S2. Sector and region classification}

Table S1. Sector classification for the current study

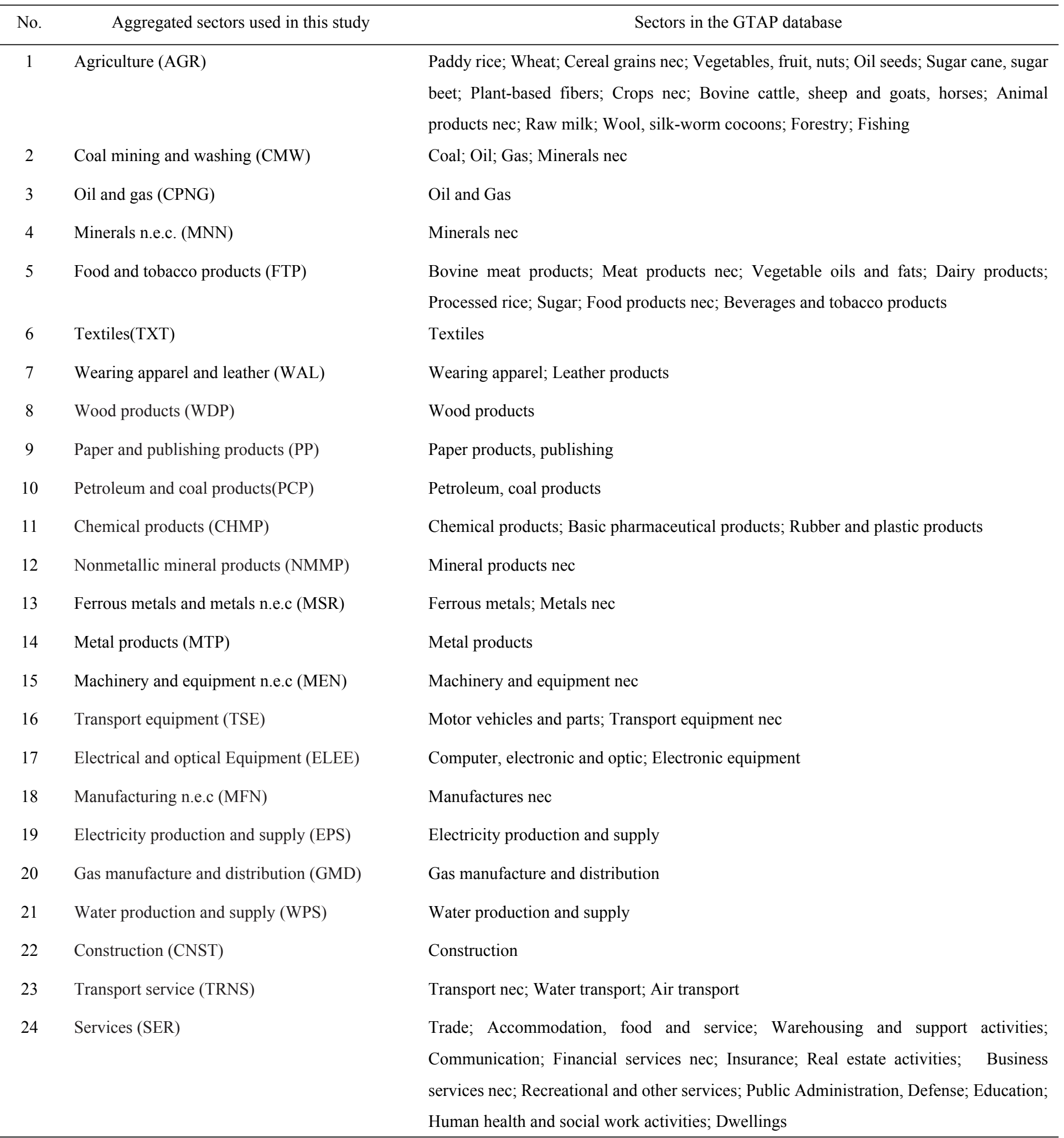

Note: According to the $\mathrm{CO}_{2}$ emissions per unit of output value of each sector under the baseline scenario, sectors 
including Coal mining and washing (CMW), Oil and gas (CPNG), Minerals n.e.c. (MNN), Petroleum and coal products(PCP), Chemical products (CHMP), Nonmetallic mineral products (NMMP), Ferrous metals and metals n.e.c (MSR), Electricity production and supply (EPS), Gas manufacturing and distribution (GMD), Transport services (TRNS), "Paper and publishing products (PP)" and "Textiles (TXT)" are classified as high-emission sectors; the remaining sectors are classified as low-emission sectors in the current study.

Table S2. Region classification for the current study

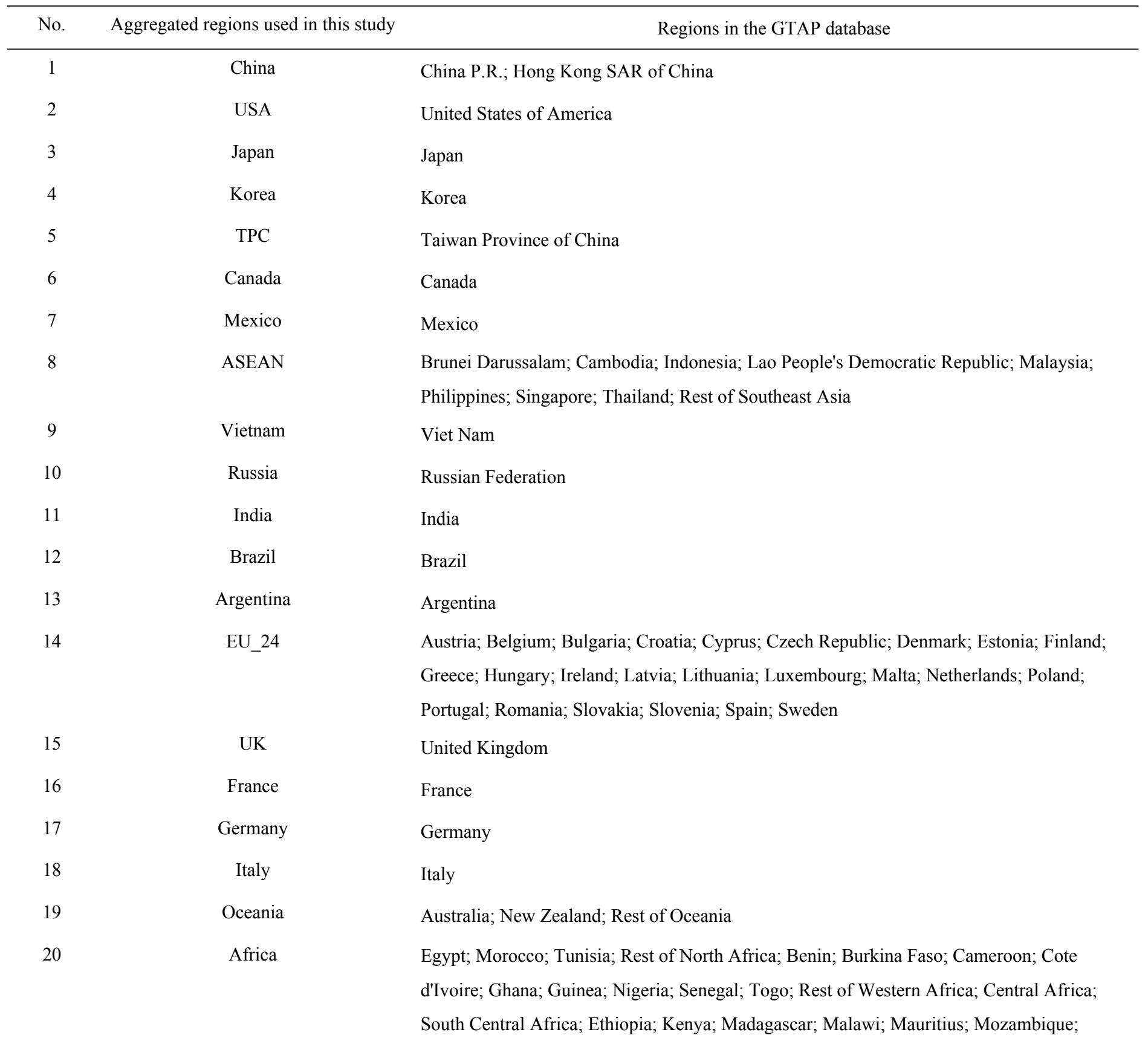


Rwanda; Tanzania; Uganda; Zambia; Zimbabwe; Rest of Eastern Africa; Botswana;

Namibia; South Africa; Rest of South African Customs

21

22

23

Rest of the World

( ROW )

\section{Kazakhstan; Kyrgyzstan; Tajikistan}

Armenia; Azerbaijan; Georgia; Bahrain; Iran Islamic Republic of; Israel; Jordan; Kuwait;

Oman; Qatar; Saudi Arabia; Turkey; United Arab Emirates; Rest of Western Asia

Mongolia; Rest of East Asia; Bangladesh; Nepal; Pakistan; Sri Lanka; Rest of South Asia;

Rest of North America; Bolivia; Chile; Colombia; Ecuador; Paraguay; Peru; Uruguay;

Venezuela; Rest of South America; Costa Rica; Guatemala; Honduras; Nicaragua; Panama;

El Salvador; Rest of Central America; Dominican Republic; Jamaica; Puerto Rico; Trinidad and Tobago; Caribbean; Switzerland; Norway; Rest of EFTA; Albania; Belarus; Ukraine; Rest of Eastern Europe; Rest of Europe; Rest of Former Soviet Union; etc.. 


\section{S3. Policy shocks for various scenarios}

In this study, it is assumed that trade policy/measures such as tariff rate adjustment and nontariff barriers first exerted impacts on the prices of traded goods and services and operational costs; then, the impacts were passed to demand and supply. These impacts then led to changes in the volume and structure of production (exports) and consumption (imports) and ultimately affected pollutant emissions and resource utilization in the exporting and importing countries. By setting different trade war scenarios (policy shocks) according to the actual situation, a computable general equilibrium (CGE) model was applied to simulate the economic and environmental impacts of the US-China trade war.

\section{S3.1 Method of combining tariff and nontariff barriers}

With the tireless efforts of the WTO and the advancement of free trade agreements, the global tariff level has been generally low, and the nontariff barriers (NTBs) have stood out as impeding factors on international trade ${ }^{17-20}$. According to ECORYS ${ }^{21}$, NTMs are defined as "all nonprice and nonquantity restrictions on trade in goods, services and investment at federal and state levels. This includes border measures (customs procedures, etc.) as well as behind-the-border measures flowing from domestic laws, regulations and practices". In short, NTBs refer to measures that impede trade.

Therefore, this study considered not only the tariff measures of the trade war but also the associated increase in nontariff barriers brought by the trade war. The quantified ad valorem equivalents (AVEs) data for nontariff barriers (NTBs) were drawn from the "Overall Trade Restriction Index" published by the World Bank and updated in July 2012, which was calculated based on Kee, et al. ${ }^{22}$. There are usually two ways to deal with the shock of nontariff measures in the CGE model: one is to use NTMs as tariff equivalents and 
adjust the tariff rate based on the AVE value; another one is to introduce it into the CGE model as an iceberg cost, constructing iceberg parameters, such as ams (i,r,s) in the GTAP model. According to the research of ECORYS ${ }^{21}$ and Kawasaki ${ }^{23}$, the costs of NTMs can be divided into two types: administrative costs and production factor costs. The former requires compulsory payment and is closer to the characteristics of taxation and should be regarded as a tax equivalent, while the latter is closer to the iceberg trade cost mainly borne by the transport sector but not by all sectors. The NTBs in this article are acknowledged to be closer to the former specification, so we took the first approach. Table S3 and S4 presents the tariff and nontariff levels of specific policy shock scenarios. The policy shock of the trade war was calculated for this study through the following formula:

$$
t m s_{\text {shock }}(i, r, s)=\left[\frac{1+\left(t m s_{0}(i, r, s)+\Delta t m s(i, r, s)+\Delta A V E s_{N T B S}(i, r, s)\right)}{1+t m s_{0}(i, r, s)}-1\right] * 100 \%
$$

where $t m s_{0}(i, r, s)$ denotes the original tariff level that country/economy s exerted on the sector i goods imported from country/economy $\mathrm{r}$ in the GTAP database, $\Delta t m s(i, r, s)$ and $\Delta A V E s_{N T B s}(i, r, s)$ denote changes in tariff and nontariff barriers exerted by country/economy s on the sector i goods imported from country/economy $\mathrm{r}$, which are negative when reduced and positive when increased.

\section{S3.2 Tariffs and AVEs of NTBs setting for various policy shock scenarios}

We first mapped the HS digit products (14,414 categories of 10-digit HS code products imported by US from China and 6,170 categories of 8-digit HS code products imported by China from the US) to 24 aggregated GTAP sectors, which means that there could be more than one product with different HS codes classified into the same GTAP sector. Then, the policy shock of the change rates of tariffs and NTBs (measured by AVEs) 
for each sector were calculated according to the weight of the import volume of commodities in total sectoral import volume in bilateral trade 24,25 .

(1) Tariffs and AVEs of NTBs setting between China and the US

According to the tariff lists implemented under the three different scenarios, the policy shocks from the tariffs and AVEs of NTBs of the US and China in this study are presented in Table S3.

Table S3. Sectoral import tariffs and AVE of NTB rates between China and the US calculated for this study, \%

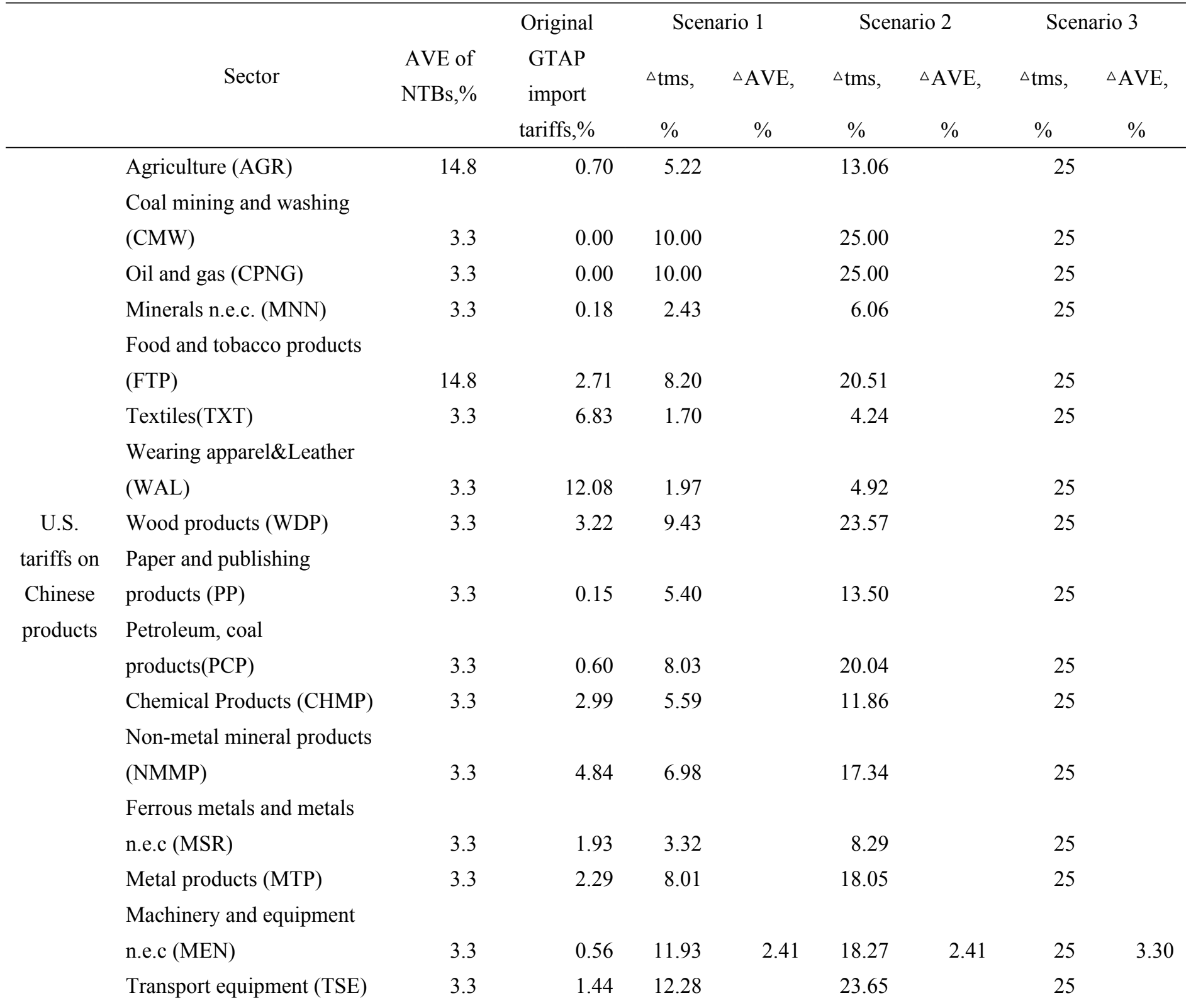




\begin{tabular}{|c|c|c|c|c|c|c|c|c|c|}
\hline & $\begin{array}{l}\text { Electrical and Optical } \\
\text { Equipment (ELEE) }\end{array}$ & 3.3 & 0.63 & 4.25 & 1.16 & 8.78 & 1.16 & 25 & 3.30 \\
\hline & Manufacturing n.e.c (MFN) & 3.3 & 1.14 & 2.31 & & 5.78 & & 25 & \\
\hline \multirow{26}{*}{$\begin{array}{c}\text { China's } \\
\text { tariffs on } \\
\text { U.S. } \\
\text { products }\end{array}$} & Agriculture (AGR) & 8.9 & 2.98 & 23.28 & 8.82 & 23.71 & 8.82 & 25 & 8.9 \\
\hline & Coal mining and washing & & & & & & & & \\
\hline & (CMW) & 4 & 0.00 & 25.00 & & 25.00 & & 25 & \\
\hline & Oil and gas (CPNG) & 4 & 4.75 & 1.66 & & 4.16 & & 25 & \\
\hline & Minerals n.e.c. (MNN) & 4 & 0.13 & 8.23 & & 19.45 & & 25 & \\
\hline & Food and tobacco products & & & & & & & & \\
\hline & (FTP) & 8.9 & 6.74 & 18.92 & & 21.47 & & 25 & \\
\hline & Textiles(TXT) & 4 & 6.40 & 6.95 & & 14.49 & & 25 & \\
\hline & Wearing apparel\&Leather & & & & & & & & \\
\hline & (WAL) & 4 & 8.93 & 6.15 & & 10.53 & & 25 & \\
\hline & Wood products (WDP) & 4 & 0.17 & 9.23 & & 16.35 & & 25 & \\
\hline & $\begin{array}{l}\text { Paper and publishing } \\
\text { products }(\mathrm{PP})\end{array}$ & 4 & 1.09 & 14.65 & & 15.14 & & 25 & \\
\hline & Petroleum, coal & & & & & & & & \\
\hline & products(PCP) & 4 & 3.14 & 25.00 & & 25.00 & & 25 & \\
\hline & Chemical Products (CHMP) & 4 & 5.73 & 6.33 & & 8.86 & & 25 & \\
\hline & Non-metal mineral products & & & & & & & & \\
\hline & (NMMP) & 4 & 8.00 & 6.44 & & 11.85 & & 25 & \\
\hline & Ferrous metals and metals & & & & & & & & \\
\hline & n.e.c (MSR) & 4 & 1.27 & 13.25 & & 20.18 & & 25 & \\
\hline & Metal products (MTP) & 4 & 8.23 & 9.12 & & 15.06 & & 25 & \\
\hline & Machinery and equipment & & & & & & & & \\
\hline & n.e.c (MEN) & 4 & 4.90 & 6.18 & & 10.17 & & 25 & \\
\hline & Transport equipment (TSE) & 4 & 11.33 & 10.54 & & 10.47 & & 25 & \\
\hline & Electrical and Optical & & & & & & & & \\
\hline & Equipment (ELEE) & 4 & 1.92 & 2.09 & & 4.60 & & 25 & \\
\hline & Manufacturing n.e.c (MFN) & 4 & 3.57 & 6.17 & & 11.83 & & 25 & \\
\hline
\end{tabular}

Note: AVEs of NTBs capture the overall level of NTBs of China and the US on their imported goods and was provided for agriculture trade products and manufacturing trade products. Data are drawn from the "Overall Trade Restriction Index" published by the World Bank and updated on July 2012, which was calculated based on Kee, et al. ${ }^{22} . \triangle$ tms are weighted rates calculated based on the bilateral import value.

(2) Tariffs and AVEs of NTBs setting between the US or China and other countries/economies or regions 
According to Nicita ${ }^{4}$, US extra tariffs on China products have resulted in a decline in imports of tariffed products by about 25 percent in the first half of 2019 . About $63 \%$ of the reduction in import from China has been replaced by imports originating from other countries/economies. Taiwan province of China, Vietnam, Mexico, EU and Korea export more machinery and equipment to the US in the first half of 2019 and benefit most by the trade diversion effects of the US-China trade war.

Affected by the trade war, China reduced import of soybeans from the US and increased 11.5 million tons in imports of soybeans from Brazil during October 2018 to March 2019 compared to the same period a year earlier ${ }^{13}$. Brazil has become the major source of Chinese soybean imports ${ }^{12,14}$. The gap in the export of US fuel export reduction to China has been filled by Saudi Arabia.

According to the roles that these countries or regions would play in the US-China trade war, this study assumed that the corresponding tariffs and NTBs between these countries/economies and the US or China in the corresponding sectors would be reduced or increased (see Table S4).

Table S4. Assumptions on the tariffs and AVEs of NTBs changes between the US or China and other countries/economies or regions

\begin{tabular}{|c|c|c|c|c|c|c|c|c|}
\hline & \multirow{2}{*}{$\begin{array}{l}\text { Country or } \\
\text { region }\end{array}$} & \multirow{2}{*}{ Sector } & \multicolumn{2}{|c|}{ Scenario1 } & \multicolumn{2}{|c|}{ Scenario3 } & \multicolumn{2}{|c|}{ Scenario2 } \\
\hline & & & $\%$ & $\%$ & $\%$ & $\%$ & $\%$ & $\%$ \\
\hline \multirow{3}{*}{$\begin{array}{l}\text { U.S. tariffs } \\
\text { on other } \\
\text { countries or } \\
\text { regions }\end{array}$} & Korea & $\begin{array}{l}\text { Machinery and equipment n.e.c } \\
(\mathrm{MEN})\end{array}$ & -0.23 & -1.65 & -0.23 & -1.65 & -0.23 & -1.65 \\
\hline & \multirow{2}{*}{$\mathrm{TPC}$} & $\begin{array}{l}\text { Machinery and equipment n.e.c } \\
(\mathrm{MEN})\end{array}$ & -1.20 & -1.65 & -1.20 & -1.65 & -1.20 & -1.65 \\
\hline & & $\begin{array}{l}\text { Electrical and Optical Equipment } \\
\text { (ELEE) }\end{array}$ & -0.45 & -1.65 & -0.45 & -1.65 & -0.45 & -1.65 \\
\hline
\end{tabular}




\begin{tabular}{|c|c|c|c|c|c|c|c|c|}
\hline & \multirow{2}{*}{ Vietnam } & $\begin{array}{l}\text { Machinery and equipment n.e.c } \\
(\mathrm{MEN})\end{array}$ & -0.39 & -1.65 & -0.39 & -1.65 & -0.39 & -1.65 \\
\hline & & $\begin{array}{l}\text { Electrical and Optical Equipment } \\
\text { (ELEE) }\end{array}$ & -0.42 & -1.65 & -0.42 & -1.65 & -0.42 & -1.65 \\
\hline & Mexico & All sectors & & & & & 5.00 & \\
\hline & \multirow{2}{*}{ EU countries } & Agriculture (AGR) & & & & & 25.00 & \\
\hline & & Transport equipment (TSE) & & & & & 10.00 & \\
\hline & Japan & Agriculture (AGR) & & & -0.50 & -7.4 & & \\
\hline Other & Japan & Agriculture (AGR) & & & -17.06 & -11.8 & & \\
\hline $\begin{array}{c}\text { regions' } \\
\text { tariffs on } \\
\text { U.S. }\end{array}$ & Canada & Food and tobacco products (FTP) & & & -0.23 & -5.7 & & \\
\hline China's & Brazil & Agriculture (AGR) & -2.97 & -4.45 & -2.97 & -4.45 & -2.97 & -4.45 \\
\hline $\begin{array}{l}\text { tariffs on } \\
\text { other }\end{array}$ & Argentina & Agriculture (AGR) & -2.96 & -4.45 & -2.96 & -4.45 & -2.96 & -4.45 \\
\hline $\begin{array}{l}\text { countries or } \\
\text { regions }\end{array}$ & WesternAsian & Oil and gas (CPNG) & 0 & -2.00 & 0 & -2.00 & 0 & -2.00 \\
\hline
\end{tabular}

Note: Tariffs removal can be assumed to be $100 \%$ for free trade but non-tariff barriers are unlikely to be cut by $100 \%$ ECORYS ${ }^{21}$ and the "actionable" (referred to by various ways possible) reduction in NTBs is assumed to be $50 \%$ of existing ones. 


\section{S4. Estimation of $\mathrm{CO}_{2}$ emissions from land use changes}

Brazil and Argentina currently are the second and third largest producers of soybean after the US. When China withdraw soybean order from the US as retaliatory trade measure in the trade war, Brazil and Argentina are likely to become a substitute for the US exporting more soybeans to China.

For Brazil, increased soybean production threatens natural vegetation cover in two ways: the first is the conversion of natural land cover to soybean cultivation; the second is the conversion of natural cover to cattle pasture and then to soybean farming ${ }^{26-29}$. The proportion of soybean plantation area expanded by destroying the natural vegetation in $2007-2013$ was $11 \% \sim 23 \%$ in the Cerrado area ${ }^{30}$. Here, the proportion rate of $23 \%$ was adopted for calculation. According to the historical production data ${ }^{31}$ we could easily calculate that 0.35 hectares of land are needed to produce 1 ton soybeans according to the current level of production technology. Based on the above, we calculated that each additional ton of soybean production led to the destruction of natural vegetation area of 0.0805 hectares.

Brazil's soybean production is concentrated in central western states, particularly in Mato Grosso, which is an agricultural frontier and a composite of the Amazon (tropical and transition deciduous and semi-deciduous forests) and Cerrado (savanna, grassland and dry forest) ecosystems ${ }^{29,32}$. This study considered the carbon emissions/losses of these two ecosystems caused by land use transition due to soybean production increases associated with the trade war. We employed the comprehensive forest reference emission level (FREL) in the Amazon and Cerrado biomes provided by Brazil under the UNFCCC ${ }^{33}$ as a reference to calculate the corresponding emission coefficient.

For Argentina, part of soybean production expansion has occurred in areas that were previously used for other crops or grazing activities, the other part originated from the transformation of native vegetation, the 
latter accounting for about $41 \%$ of the expansion of soybean plantations. ${ }^{34,35}$ With the current production technology, 0.36 hectares of land are needed to produce 1 ton soybeans ${ }^{31}$. Therefore, the deforestation coefficient for soybean plantation in Argentina is approximately 0.148 hectares per ton soybean. The carbon emission factor for forest land use change in Argentina was drawn from Food and Agriculture Organization of the United Nations (FAO). ${ }^{31}$

We then assume that changes in the output value of Brazil and Argentina's "Agriculture" sector are all from the changes in soybean output. Then we can get Brazil and Argentina 's $\mathrm{CO}_{2}$ emissions from land use change caused by the US-China trade war from the formula,

$$
\begin{gathered}
Q_{L}=S_{\text {occ }} \times F R E L=0.0805 \times \Delta O_{\text {soybean,prc }} \times X_{\text {soybean }} \times F R E L \\
\Delta O_{\text {soybean,prc }}=\Delta O_{\text {agriculture,prc }} / \frac{O_{\text {soybean }}}{O_{\text {agricultrue }}}
\end{gathered}
$$

where $Q_{L}$ is $\mathrm{CO}_{2}$ emissions from land use changes caused by the US-China trade war; $X_{\text {soybean }}$ is annual quantity of soybean production in Brazil or Argentina; FREL is the forest reference emission level (FREL) in Brazil ${ }^{33}$ or Argentina ${ }^{31} ; \Delta O_{\text {soybean,prc }}$ is $\%$ change in soybean production of Brazil or Argentina caused by the US-China trade war; $\Delta O_{\text {agriculture,prc }}$ is \% change in output value of "Agriculture" sector in Brazil or Argentina caused by the US-China trade war which we can obtain from the GTAP model; $O_{\text {soybean }}$ and $O_{\text {agricultrue }}$ are Brazil or Argentina 's soybean output value and "Agriculture" sector output value, respectively. $S_{o c c}$ is the natural vegetation area occupied by Brazil or Argentina's soybean plantation expansion due to the trade war, which is estimated to be approximately $626,251 \sim 859,637$ hectares in Brazil and 247,634 310,859 hectares in Argentina.

The natural land occupancy estimated in this study is much smaller than what Fuchs, et al. ${ }^{14}$ predicted, because this study considers that only $23 \%$ of the increase in soybean plantation area in Brazil is from the 
conversion of natural vegetation, and the rest of it is from the conversion of existing pastures. Thus this study adopted a relatively conservative estimation method for $\mathrm{CO}_{2}$ emissions from land use changes. If the strong assumption of Fuchs, et al. ${ }^{14}$ is adopted, that is, all producers cover the US shortfall and the increase in soybean production totally depends on the expansion of land, annual $\mathrm{CO}_{2}$ emission increase will reach 2,211,574.86 kt. 


\section{S5. Data sources and processing methods}

The National and sectoral $\mathrm{CO}_{2}$ emissions data were drawn from EDGARv5.0 ${ }^{36}$ and the GTAP database 37, which has been updated up to 2014. The GTAP database only has $\mathrm{CO}_{2}$ emissions data of fossil fuel combustion, but does not include emissions from residential activities (such as heating), private, and the process-related emissions (such as cement production). EDGARv5.0 reports $\mathrm{CO}_{2}$ emissions from fossil fuel combustion, industrial processes (cement, steel, chemical and urea production) and product use. The energy use data of GTAP and EDGAR used to estimate $\mathrm{CO}_{2}$ from fossil fuel consumption from 1970-2015 were drawn from IEA. The sectoral data of EDGAR were reported using the IPCC code, which did not match with the GTAP sectors. Therefore, this study quoted the total $\mathrm{CO}_{2}$ emissions of fossil fuel combustion from EDGARv5.0 and reallocated the total emissions to the sectors of the GTAP database according to the sectoral emission structure. Emissions from industrial processes in EDGARv5.0 were also allocated to corresponding sectors in GTAP. Through the above steps, the $\mathrm{CO}_{2}$ emissions dataset used in this article was produced. This method can be expressed as follows:

$$
Q_{i, n}=\sum_{f} Q_{f, n}^{E D G A R} \times \frac{Q_{i, n}^{G T A P}}{\sum_{i} Q_{i, n}^{G T A P}}+Q_{p, n}^{E D G A R}
$$

where $Q_{i, n}$ is the $\mathrm{CO}_{2}$ emissions in aggregated sector i of country/region n; $Q$ EDGAR is the EDGAR $\mathrm{CO}_{2}$ emissions data of IPCC code f, which represents different kinds of fossil fuel combustion activity in country/region n; $Q_{i, n}^{G T A P}$ is the GTAP $\mathrm{CO}_{2}$ emissions data for sector $\mathrm{i}$ and country/region $\mathrm{n} ; Q_{p, n}^{E D G A R}$ is the EDGAR $\mathrm{CO}_{2}$ emissions data for IPCC code $\mathrm{p}^{38}$, which represents different kinds of industrial processes in country/region $\mathrm{n}$; i corresponds to $\mathrm{p}$; when $\mathrm{p}=2 \mathrm{~A} 1,2 \mathrm{~A} 2$, 2A3, $2 \mathrm{~A} 4$ and $2 \mathrm{~A} 7, \mathrm{i}=\mathrm{NMMP}$; when $\mathrm{p}=2 \mathrm{~B}, \mathrm{i}=\mathrm{CHMP}$; when $\mathrm{p}=2 \mathrm{C}, \mathrm{i}=\mathrm{MSR}$ (the full names of aggregate GTAP sectors are listed in Table S1). 


\section{S6. Predicted country/economy-wide and sectoral $\mathrm{CO}_{2}$ emission changes}

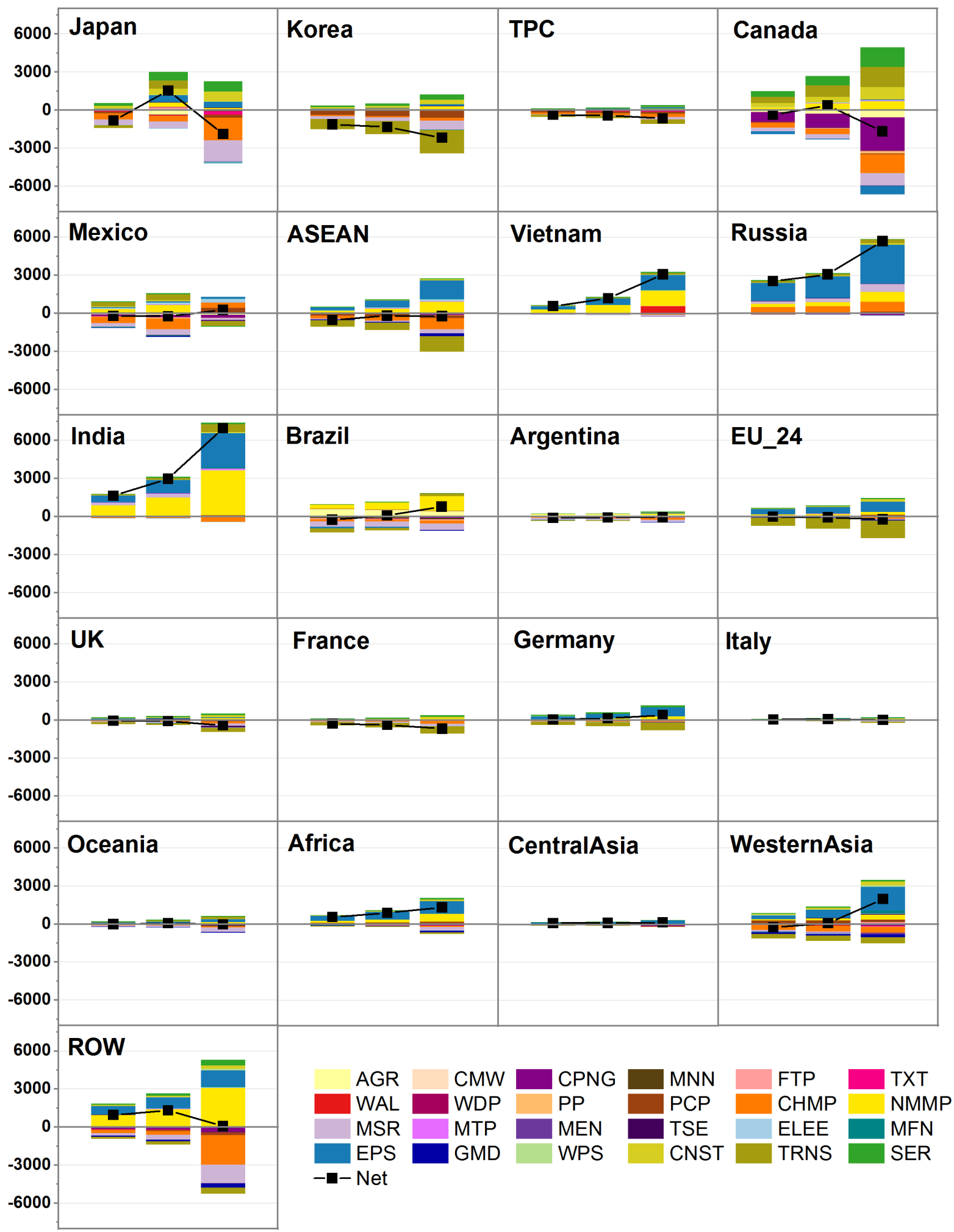

Figure S2. Predicted country/economy-wide and sectoral $\mathrm{CO}_{2}$ emission changes in three scenarios, $\mathrm{kt}$.

$\mathrm{CO}_{2}$ emission changes from Brazil land use change are not included here. TPC is short for Taiwan Province of China. 
Table S5. Driving force decomposition for annual $\mathrm{CO}_{2}$ emission changes, $\mathrm{kt}$

\begin{tabular}{|c|c|c|c|c|c|c|c|c|c|}
\hline & \multicolumn{3}{|c|}{ Scenario 1} & \multicolumn{3}{|c|}{ Scenario 2} & \multicolumn{3}{|c|}{ Scenario 3} \\
\hline & $\begin{array}{l}\text { Scale } \\
\text { effect }\end{array}$ & $\begin{array}{c}\text { Structure } \\
\text { effect }\end{array}$ & $\begin{array}{c}\text { Net } \\
\text { effect }\end{array}$ & $\begin{array}{l}\text { Scale } \\
\text { effect }\end{array}$ & $\begin{array}{c}\text { Structure } \\
\text { effect }\end{array}$ & $\begin{array}{c}\text { Net } \\
\text { effect }\end{array}$ & $\begin{array}{l}\text { Scale } \\
\text { effect }\end{array}$ & $\begin{array}{c}\text { Structure } \\
\text { effect }\end{array}$ & $\begin{array}{c}\text { Net } \\
\text { effect }\end{array}$ \\
\hline China & -52608 & 7853 & -44755 & -67084 & 4135 & -62949 & -113729 & 29919 & -83810 \\
\hline USA & -26016 & 6463 & -19552 & -45891 & 11605 & -34286 & -104346 & 25028 & -79318 \\
\hline Japan & 567 & -1387 & -820 & 3805 & -2257 & 1548 & 1588 & -3475 & -1888 \\
\hline Korea & 793 & -1924 & -1131 & 1100 & -2432 & -1332 & 2554 & -4735 & -2182 \\
\hline TPC & 483 & -843 & -360 & 667 & -1077 & -411 & 1254 & -1907 & -653 \\
\hline Canada & 4161 & -4531 & -369 & 7016 & -6642 & 373 & 14549 & -16226 & -1677 \\
\hline Mexico & 992 & -1199 & -206 & 1471 & -1717 & -245 & 94 & 171 & 265 \\
\hline ASEAN & 661 & -1186 & -524 & 1801 & -1986 & -186 & 4633 & -4862 & -229 \\
\hline Vietnam & 975 & -384 & 591 & 1729 & -530 & 1198 & 4209 & -1116 & 3094 \\
\hline Russia & 1538 & 1006 & 2544 & 1899 & 1186 & 3085 & 3634 & 2074 & 5708 \\
\hline India & 1337 & 302 & 1639 & 2440 & 534 & 2975 & 7171 & -201 & 6970 \\
\hline Brazil & -36 & -218 & -253 & 268 & -183 & 85 & 1347 & -572 & 775 \\
\hline Argentina & -83 & -31 & -114 & -14 & -61 & -75 & 178 & -242 & -64 \\
\hline EU_24 & 851 & -871 & -20 & 1291 & -1352 & -61 & 2285 & -2505 & -221 \\
\hline UK & 468 & -526 & -58 & 660 & -736 & -76 & 869 & -1274 & -405 \\
\hline France & 453 & -727 & -273 & 653 & -1024 & -371 & 1013 & -1694 & -681 \\
\hline Germany & 751 & -706 & 45 & 991 & -848 & 144 & 672 & -283 & 389 \\
\hline Italy & 122 & -74 & 48 & 156 & -85 & 71 & 220 & -217 & 4 \\
\hline Oceania & 661 & -671 & -10 & 968 & -884 & 83 & 2236 & -2252 & -16 \\
\hline Africa & 614 & -41 & 573 & 910 & -14 & 895 & 2152 & -829 & 1322 \\
\hline CentralAsia & 107 & -9 & 97 & 167 & -54 & 113 & 352 & -189 & 164 \\
\hline WesternAsia & 901 & -1151 & -250 & 1414 & -1333 & 81 & 3758 & -1784 & 1974 \\
\hline RestofWorld & 1677 & -713 & 964 & 2506 & -1193 & 1314 & 6676 & -6601 & $\begin{array}{c}74 \\
-\end{array}$ \\
\hline Total & -60629 & -1568 & -62197 & -81078 & -6948 & -88026 & -156631 & 6228 & 150403 \\
\hline
\end{tabular}

Note: $\mathrm{CO}_{2}$ emission changes caused by land use change in Brazil were not counted here. TPC is short for Taiwan Province of China. 


\section{S8. Economic impacts of US-China trade war}

\section{S8.1 Impacts on GDP}

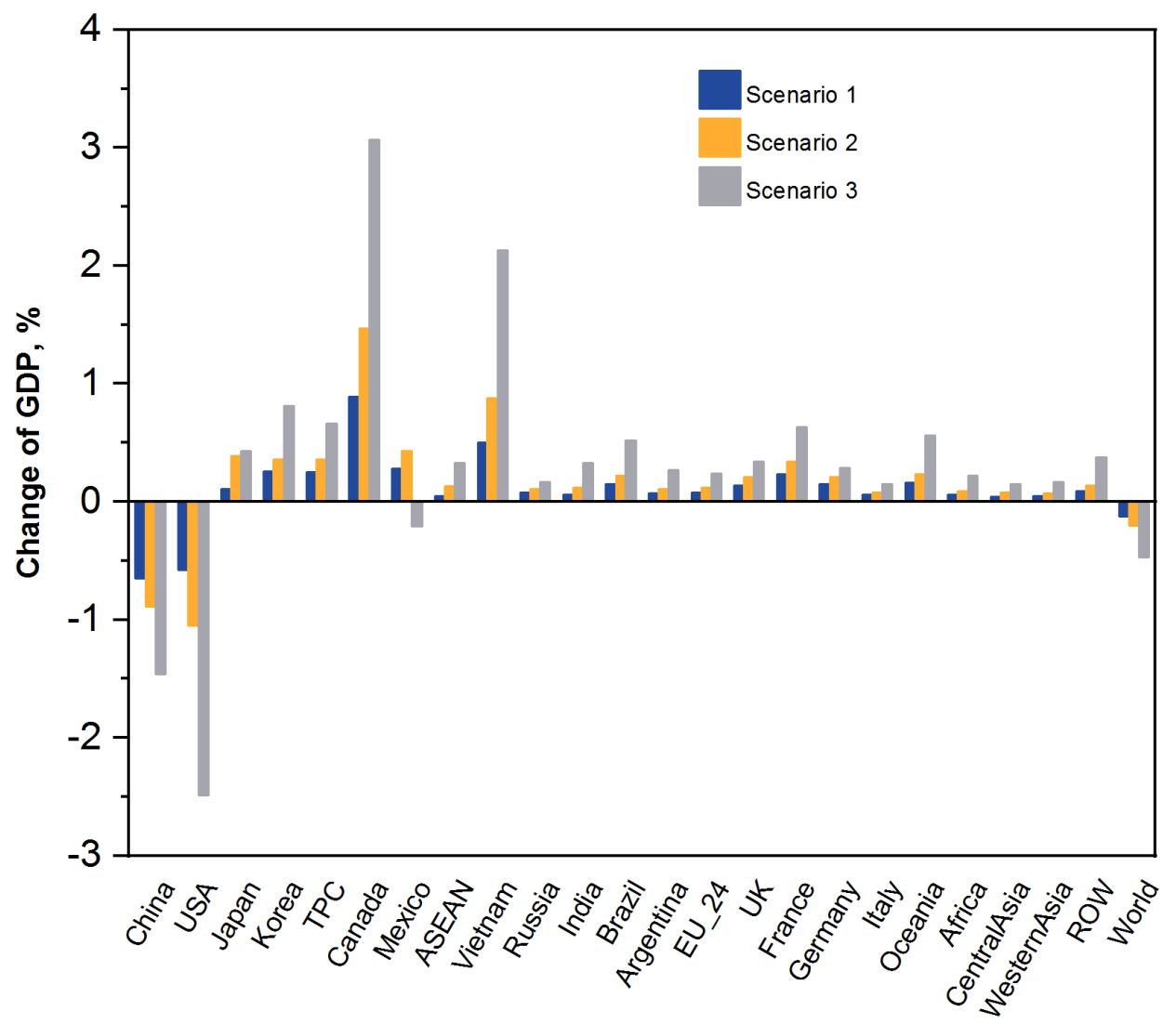

Figure S3. Impacts of trade war on GDP in different countries or regions in three scenarios. TCP is for Taiwan

Province of China

According to the GTAP simulation, the GDPs of China and the US will decrease and the GDPs of other countries/economies will increase to a certain extent. GDP of China will fall by $0.65 \% \sim 1.46 \%$, while the US's GDP will decrease by $0.58 \% \sim 2.49 \%$, showing a lose-lose situation.

Countries/economies such as Canada, Vietnam, Korea, and Taiwan Province of China, which have strong complementarities with China and the US, will benefit from the US-China trade war because of trade 
diversion effect. Among them, Canada and Vietnam will benefit the most with the increases of GDP of $0.89 \% \sim 3.07 \%$ and $0.50 \% \sim 2.13 \%$, respectively. Korea will see GDP increase of $0.26 \% \sim 0.82 \%$ and Taiwan Province of China will see GDP increase of $0.25 \% \sim 0.66 \%$. For Mexico, GDP will increase by $0.28 \%$ and $0.43 \%$ under Scenario 1 and 2 but decrease by $0.21 \%$ under Scenario 3.

Over all, although most parts of the world will benefit from trade diversion effects, the economy scales of China and the US are the largest two and when their GDPs are greatly affected, the global GDP will decline by $0.13 \% \sim 0.47 \%$.

Comparisons with other studies of potential impacts on GDP changes of the US-China trade war is presented in Table S6.

Table S6. Simulated GDP changes caused by the US-China trade war in different studies

\begin{tabular}{|c|c|c|c|c|}
\hline & \multicolumn{3}{|c|}{ GDP decrease } & \multirow{2}{*}{ Scenario description } \\
\hline & China & USA & World & \\
\hline This study & $0.64 \%-1.46 \%$ & $0.58 \%-2.49 \%$ & $0.13 \%-0.47 \%$ & See manuscript section 2.2 . \\
\hline $\begin{array}{l}\text { Goldman Sachs } \\
3\end{array}$ & $0.4 \%-1.0 \%$ & $0.5 \%-1.2 \%$ & $0.3 \%-0.6 \%$ & $\begin{array}{l}\text { The US imposes a } 10 \% \text { tariff on the final tranche of } \$ 300 \\
\text { billion of Chinese imports and all imports from Mexico. }\end{array}$ \\
\hline Itakura ${ }^{8}$ & $1.13 \%-1.41 \%$ & $0.37 \%-1.35 \%$ & $0.2 \%-0.3 \%$ & $\begin{array}{l}\text { 1.Related countries or regions raise their import tariffs; } \\
\text { 2.Scenario } 1+\text { the trade war is assumed to deter foreign } \\
\text { investment in the USA and China; } 3 . \text { Scenario } 1+\text { Scenario } \\
2+\text { the trade war is assumed to worsen productivity in the } \\
\text { USA and China. }\end{array}$ \\
\hline $\mathrm{KPMG}^{42}$ & $0.6 \%-5.3 \%$ & $0.4 \%-4.6 \%$ & $0.4-3.5 \%$ & $\begin{array}{l}\text { 1.Limited escalation, no contagion: the restriction of the } \\
\text { current trade war between the US and China to already } \\
\text { announced tariff increases; } 2 . \text { Full escalation, no contagion: } \\
\text { an escalation of tariffs to } 25 \% \text { between China and the US; } \\
\text { 3.Full escalation, full contagion: a substantial number of } \\
\text { other countries joined in and raised tariffs by } 15 \% \text {. }\end{array}$ \\
\hline $\mathrm{IMF}^{43}$ & $0.5 \%-1.5 \%$ & $0.3 \%-0.6 \%$ & - & $\begin{array}{l}\text { Use four kinds of model to simulate the impacts of tariffs on } \\
\text { all US-China goods trade increase by } 25 \% \text {. }\end{array}$ \\
\hline
\end{tabular}




\section{S8.2 Impacts on trade structure}

Affected by the trade war, the trade flows between China, the US and the other countries/economies will change. Global trade volume will shrink by $0.42 \% \sim 1.17 \%$ under the three Scenarios. Fig S4 shows main flow changes between China, the US and other countries/economies.

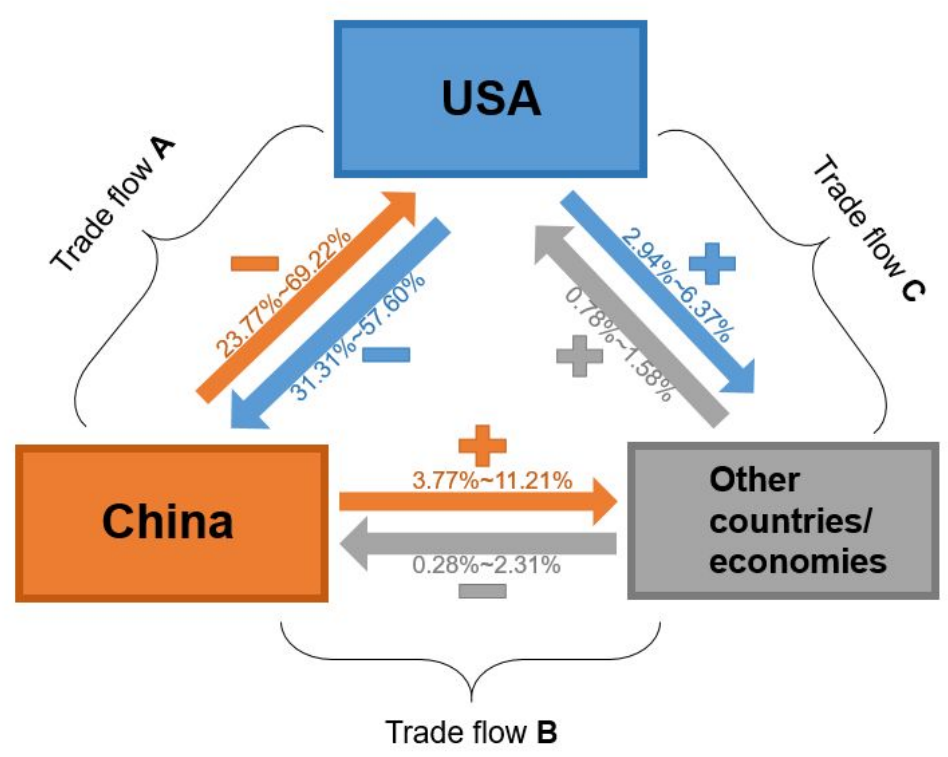

Figure S4. Predicted trade flow changes between China, the US and the other countries under the trade war In this figure, trade flow A, B and C represent changes in bilateral trade between China and the US, China and other countries/economies, the US and other countries/economies, respectively.

According to the simulation results, the US-China trade war indeed hits Chinese and the US bilateral trade. Chinese exports to the US will decrease by $23.77 \% \sim 69.22 \%$ while the US exports to China will decrease by $31.31 \% \sim 57.60 \%$ and the largest bilateral export declines will both occur under Scenario 3.

Trade diversion effects of the trade war will promote China transfer its exports from the US to other countries/economies and the export value will increase by $3.77 \% \sim 11.21 \%$. Countries/economies other than 
China and the US will increase their exports to the US ${ }^{44}$ by $0.78 \%-1.58 \%$ after accepting more Chinese exports but reduce their exports to China by $0.28 \% \sim 2.31 \%$. The US will expand export to other countries/economies by $2.49 \%-6.37 \%$.

Figure S5 shows the detailed changes of trade flow between different countries/economies and regions. For countries/economies or regions other than China and the US, the US-China trade war will strengthen their trade ties with China and the US, and weakens trade tightness between themselves. For example, total exports of Taiwan Province of China, Vietnam, Korea, and ASEAN to the US will increase the most. As the trade war expands and deepens, their exports to the US will increases. At the same time, their exports to other countries/economies and regions decrease. Brazil, Argentina and Western Asia countries' exports to China will increase to bridge the gap in China's soybean and energy products demand. 


\section{Exporters}

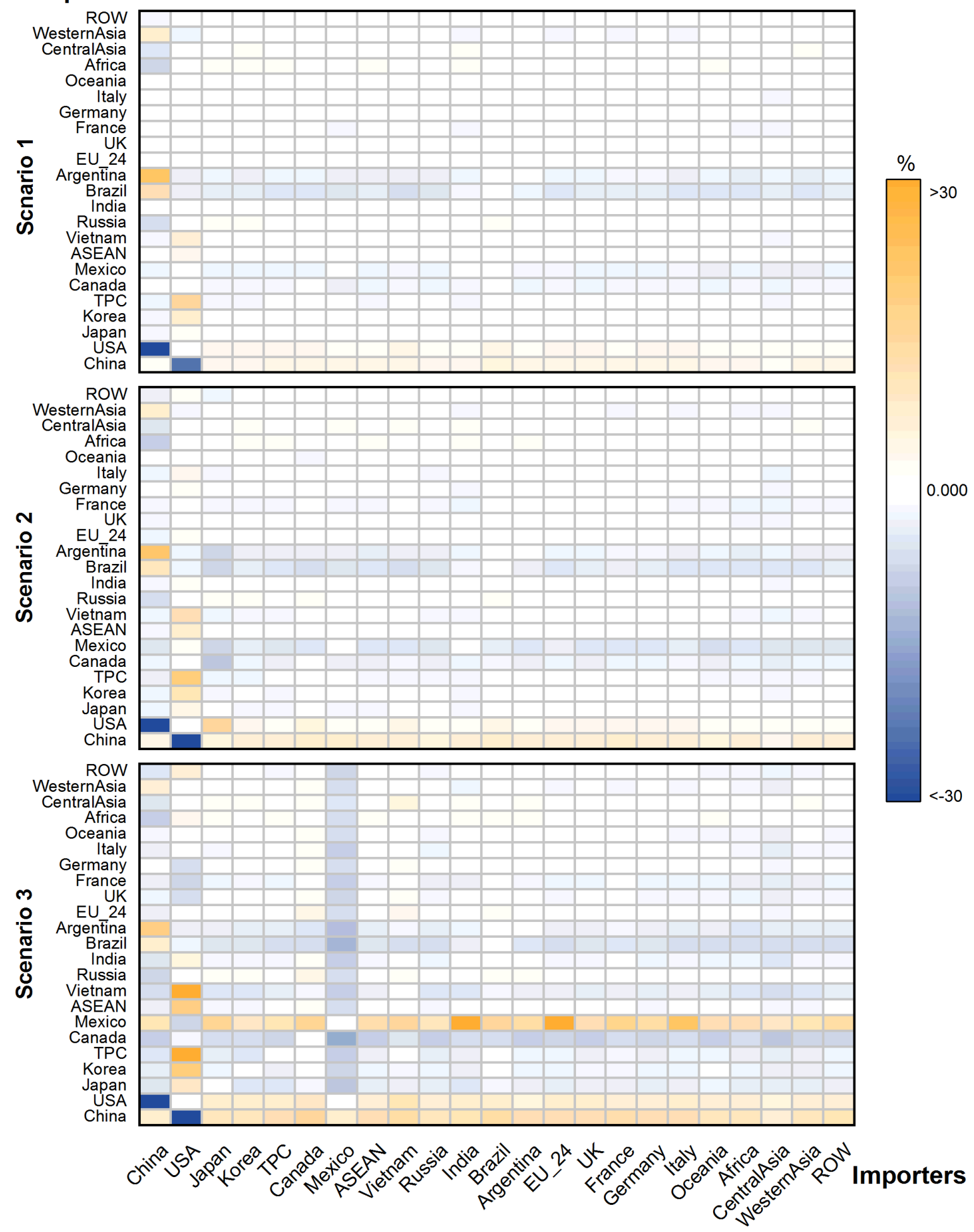

Figure S5. Changes of trade flow between different countries/economies and regions under trade war scenarios

Note: TCP is for Taiwan Province of China 


\section{Reference}

1. United Nations. UN Comtrade Database. https://comtrade.un.org/data/

2. Ministry of Commerce of China (MOFCOM). Research Report on China-US Economic and Trade Relations by Ministry of Commerce of China; Ministry of Commerce of China: Beijing, China, 2017.

3. Goldman Sachs. Trade War 3.0; New York, 2019; pp 12-21.

4. Nicita, A. Trade and Trade Diversion Effects of United States tariffs on China; 37; UNCTAD: Geneva, Switzerland, 2019.

5. Amiti, M.; Redding, S. J.; Weinstein, D. The Impact of the 2018 Trade War on U.S. Prices and Welfare. National Bureau of Economic Research Working Paper Series 2019, 25672.

6. Zoller-Rydzek, B.; Felbermayr, G. Who is Paying for the Trade War with China?; EconPol: Munich, Germany, 2018; pp 3-11.

7. Devarajan, S.; Go, D. S.; Lakatos, C.; Robinson, S.; Thierfelder, K. Traders' Dilemma -Developing Countries' Response to Trade Disputes. The World Bank Policy Research Working Paper 2018, 8640, 1-18.

8. Itakura, K. Evaluating the Impact of the US-China Trade War. Asian Economic Policy Review 2020, $15,(1), 77-93$.

9. Li, C.; He, C.; Lin, C. Economic Impacts of the Possible China-US Trade War. Emerging Markets Finance and Trade 2018, 54, (7), 1557-1577.

10. Lu, L.; Sheng, L.; Yu, M.; Guo, M. The Day After Tomorrow: Evaluating the Burden of Trump's Trade War. ASIAN ECON PAP 2018, 17, (1), 101-120.

11. Hopkinson, J. Profiles and Effects of Retaliatory Tariffs on U.S. Agricultural Exports; Congressional Research Service: 2018.

12. Adjemian, M. K.; Smith, A.; He, W., Estimating the Market Effect of a Trade War: The Case of Soybean Tariffs. In 2019 Annual Meeting, July 21-23, Atlanta, Georgia, Agricultural and Applied Economics Association: 2019.

13. Gale, F.; Valdes, C.; Ash, M. Interdependence of China, United States, and Brazil in Soybean Trade; United States Department of Agriculture: Washington, D.C, 2019.

14. Fuchs, R.; Alexander, P.; Brown, C.; Cossar, F.; Henry, R. C.; Rounsevell, M. Why the US-China trade war spell disaster for the Amazon. nature 2019, 567, 451-454.

15. Eugster, J.; Jaumotte, F.; MacDonald, M.; Piazza, R. World economic outlook: Chapter 4. The drivers of bilateral trade and the spillovers from tariffs; International Monetary Fund: Washington, DC, USA, 2019; pp 103-128.

16. Sun, C.; Tao, Z.; Yuan, H.; Zhang, H. The Impact of the US-China Trade War on Japanese Multinational Corporations; Research Institute of Economy, Trade and Industry (RIETI): Jul, 2019.

17. Cadot, O.; Gourdon, J. Non-tariff measures, preferential trade agreements, and prices: new evidence. Review of World Economics 2016, 152, (2), 227-249.

18. Carrère, C.; de Melo, J. Non-Tariff Measures: What Do We Know, What Might Be Done? Journal of Economic Integration 2011, 26, (1), 169-196.

19. Grundke, R.; Moser, C. Hidden protectionism? Evidence from non-tariff barriers to trade in the United States. Journal of International Economics 2019, 117, 143-157.

20. World Trade Organization (WTO). World Trade Report 2012: Trade and public policies: A closer look at non-tariff measures in the 21st century; WTO: Geneva, 2012. 
21. ECORYS. Non-Tariff Measures in EU-US Trade and Investment-An Economic Analysis; ECORYS: Nederland, 2009.

22. Kee, H. L.; Nicita, A.; Olarreaga, M. Estimating trade restrictiveness indices. The Economic Journal 2009, 119, 539.

23. Kawasaki, K. The relative significance of EPAs in Asia-Pacific. Journal of Asian Economics 2015, 39, 19-30.

24. United States International Trade Commission (USITC). https://dataweb.usitc.gov/

25. China, G. A. o. C. P. R. http://www.customs.gov.cn/eportal/ui?pageId=302275

26. Morton, D. C.; DeFries, R. S.; Shimabukuro, Y. E.; Anderson, L. O.; Arai, E.; del Bon Espirito-Santo, F.; Freitas, R.; Morisette, J. Cropland expansion changes deforestation dynamics in the southern Brazilian Amazon. Proceedings of the National Academy of Sciences 2006, 103, (39), 14637.

27. Barona, E.; Ramankutty, N.; Hyman, G.; Coomes, O. T. The role of pasture and soybean in deforestation of the Brazilian Amazon. Environmental Research Letters 2010, 5, (2), 024002.

28. Nepstad, D. C.; Stickler, C. M.; Almeida, O. T. Globalization of the Amazon Soy and Beef Industries: Opportunities for Conservation. Conservation Biology 2006, 20, (6), 1595-1603.

29. Lathuillière, M. J.; Miranda, E. J.; Bulle, C.; Couto, E. G.; Johnson, M. S. Land occupation and transformation impacts of soybean production in Southern Amazonia, Brazil. Journal of Cleaner Production 2017, 149, 680-689.

30. Gibbs, H. K.; Rausch, L.; Munger, J.; Schelly, I.; Morton, D. C.; Noojipady, P.; Soares-Filho, B.; Barreto, P.; Micol, L.; Walker, N. F. Brazil' s Soy Moratorium. Science 2015, 347, (6220), 377.

31. Food and Agriculture Organization of the United Nations (FAO). FAOSTAT database. http://www.fao.org/faostat/en/\#home

32. Macedo, M. N.; DeFries, R. S.; Morton, D. C.; Stickler, C. M.; Galford, G. L.; Shimabukuro, Y. E. Decoupling of deforestation and soy production in the southern Amazon during the late 2000s. Proceedings of the National Academy of Sciences 2012, 109, (4), 1341.

33. United Nations Framework Convention on Climate Change (UNFCCC). Reporting to the UNFCCCBrazil. https://redd.unfccc.int/submissions.html?country=BR.

34. Goldfarb, L.; Zoomers, A. The Drivers Behind the Rapid Expansion of Genetically Modified Soya Production into the Chaco Region of Argentina. https://www.intechopen.com/books/biofuels-economyenvironment-and-sustainability/the-drivers-behind-the-rapid-expansion-of-genetically-modified-soyaproduction-into-the-chaco-region

35. Grau, H. R.; Gasparri, N. I.; Aide, T. M. Agriculture expansion and deforestation in seasonally dry forests of north-west Argentina. Environmental Conservation 2005, 32, (2), 140-148.

36. Muntean, M.; Guizzardi, D.; Schaaf, E.; Crippa, M.; Solazzo, E.; Olivier, J. G. J.; Vignati, E. Fossil CO2 emissions of all world countries - 2018 Report; 978-92-79-97240-9; Publications Office of the European Union: Luxembourg, 2018.

37. Aguiar, A.; Chepeliev, M.; Corong, E. L.; McDougall, R.; van der Mensbrugghe, D. The GTAP Data Base: Version 10. Journal of Global Economic Analysis 2019, 4, (1).

38. IPCC. 2006 IPCC Guidelines for National Greenhouse Gas Inventories. https://www.ipccnggip.iges.or.jp/public/2006gl/

39. OECD. OECD Database. https://stats.oecd.org/

40. Crippa, M.; Guizzardi, D.; Muntean, M.; Schaaf, E.; Dentener, F.; van Aardenne, J. A.; Monni, S.; 
Doering, U.; Olivier, J. G. J.; Pagliari, V.; Janssens-Maenhout, G. Gridded emissions of air pollutants for the period 1970-2012 within EDGAR v4.3.2. Earth Syst. Sci. Data 2018, 10, (4), 1987-2013.

41. International Energy Agency (IEA). https://www.iea.org/data-andstatistics? country=WORLD\&fuel $=$ Energy $\% 20$ supply\&indicator $=$ Total $\% 20$ primary $\% 20$ energy $\% 20$ supply $\%$ 20(TPES) $\% 20$ by $\% 20$ source

42. KPMG. Trade Wars: There are no winners; KPMG Economics \& Tax Centre: 2018.

43. IMF. World economic outlook (International Monetary Fund); International Monetary Fund: Washington, DC, 2019; pp 124-128.

44. Lovely, M. E.; Liang, Y. Trump Tariffs Primarily Hit Multinational Supply Chains, Harm US Technology Competitiveness.; Peterson Institute for International Economics: Washington, 2018. 